\title{
When roads cross streams: fish assemblage responses to fluvial fragmentation in lowland Amazonian
} a streams

Correspondence: Gabriel L. Brejão gbrejao@gmail.com

Submitted June 4, 2019

Accepted July 15, 2020

by Lilian Casatti

Epub September 04, 2020

Online version ISSN 1982-0224

Print version ISSN 1679-6225

Neotrop. Ichthyol.

vol. 18, no. 3, Maringá 2020

\author{
${ }^{\oplus}$ Gabriel L. Brejão ${ }^{1},{ }^{\oplus}$ Fabrício B. Teresa ${ }^{2}$ and ${ }^{\oplus}$ Pedro Gerhard ${ }^{3}$
}

Roads affect biodiversity by increasing mortality rates, habitat loss, and natural landscape fragmentation. Poorly installed culverts can impound streams, changing the environmental conditions, and affecting aquatic communities. We evaluated the effects of road crossings on the taxonomic composition and functional structure of fish assemblages in lowland eastern Amazonian streams, Brazil. We tested the hypothesis that the presence of road-derived impoundments affects assemblage taxonomic and functional composition and structure. Two predictions were addressed: (1) Species and functional group composition will differ in impounded reaches in relation to lotic reaches; (2) Assemblages in downstream lotic reaches will be richer in species and functional groups in relation to upstream lotic and impoundment reaches. We sampled five streams crossed by roads presenting impoundment formation, conducted by visual census (day, dusk, and night) in $200 \mathrm{~m}$ line transects. Assemblage composition from lentic reaches was different from lotic reaches, and Shannon diversity from downstream reaches was different from upstream and impoundment, however, beta diversity partitioning between lotic reaches showed higher nestedness contribution, reinforcing the role of impoundment in limiting fish dispersal between lotic reaches. These results suggest that impoundments impose environmental and dispersal constraints to fish, affecting their longitudinal distribution in streams fragmented by roads.

Keywords: Deforestation arc, Dispersal-based process, Niche-based process, NMDS, Snorkeling

1 Departamento de Zoologia e Botânica, Universidade Estadual Paulista “Júlio de Mesquita Filho”, Rua Cristóvão Colombo, 2265, 15054-000 São José do Rio Preto, SP, Brazil. (GLB) gbrejao@gmail.com (corresponding author).

2 Universidade Estadual de Goiás, Campus de Ciências Exatas e Tecnológicas, Rodovia BR-153, 3105, 75132-903 Anápolis, GO, Brazil. (FBT) fabricioteresa@yahoo.com.br.

3 Embrapa, Rodovia SP-340, Km 127.5, 13918-110 Jaguariúna, SP, Brazil. (PG) pedro.gerhard@gmail.com. 
Estradas afetam a biodiversidade aumentando as taxas de mortalidade, perda de hábitat e fragmentação. Cruzamentos mal instalados represam riachos, alterando as condições ambientais e afetando as comunidades aquáticas. Avaliamos os efeitos deste impacto sobre a estrutura taxonômica e funcional das assembleias de peixes em riachos da Amazônia Oriental, Brasil. Testamos a hipótese de que a presença dos alagados derivados de estradas afeta a composição e estrutura taxonômica e funcional das assembleias. Nossas predições foram: (1) A composição de espécies e grupos funcionais é diferente entre trechos alagados e lóticos; (2) Assembleias nos trechos à jusante serão mais ricas em espécies e grupos funcionais que os trechos à montante e alagados. Amostramos cinco riachos cruzados por estradas com formação de alagamentos por censo visual (dia, crepúsculo e noite) em transectos lineares de $200 \mathrm{~m}$. A composição das assembleias dos trechos lênticos diferiu dos lóticos, e a diversidade de Shannon à jusante diferiu dos trechos montante e alagados, entretanto, nos lóticos, houve maior contribuição do aninhamento na partição da diversidade beta, reforçando o papel do represamento na limitação da dispersão de peixes entre estes. Sugerimos que os represamentos impõem restrições ambientais e de dispersão aos peixes, afetando sua distribuição longitudinal em riachos fragmentados por estradas.

Palavras-chave: Arco do desmatamento, Mergulho-livre, NMDS, Processos baseados em dispersão, Processos baseados em nicho.

\section{INTRODUCTION}

Despite many benefits that roads bring to human populations, they affect negatively biodiversity by increasing rates of mortality, habitat loss, and fragmentation of natural landscapes (Forman, Alexander, 1998; Spellerberg, 1998; Laurance et al., 2009). Given the importance of this issue, biological impacts of roads have been widely assessed for several taxonomic groups (Vos, Chardon, 1998; Haskell, 2000; Benítez-López et al., 2010). However, the evaluation of the extent by which roads affect biodiversity is still a challenge, especially in biodiversity-rich regions where there is knowledge shortfall on different facets of biodiversity (Hortal et al., 2015). Worst, this condition contrasts with the rapid human occupation that is accomplished by unplanned infrastructure development (Develey, Stouffer, 2001).

In streams crossed by roads, if crossing structures are poorly installed, they may alter flow and occasionally block fish passage. In such cases, water will tend to flood the stream reach upstream the road, with undersized culverts acting as damming structures. These impoundments will develop into deep habitats, with slow water flows and a silty substrate, conditions that are very distinct if compared to the natural course of the stream (Wellman et al., 2000). As a consequence, the fluvial habitat continuum becomes fragmented. These alterations result in habitat loss and fragmentation, which in turn influence species persistence and assemblage structure (Lake, 2000; Makrakis et al., 2012; Mariano et al., 2012).

Species functional traits influence their responses to habitat alterations (Violle et al., 
2007; 2012), so that changes in community composition would occur in a non-random way (Keck et al., 2014). In the context of stream fragmentation caused by crossing structures, rheophilic and intolerant species may be negatively influenced (Rolls et al., 2014), as conditions in the impoundment would represent a barrier. Otherwise, limnophilic species can benefit and successfully explore these new environments (Warren Jr., Pardew, 1998). Therefore, one could expect that variations in species composition in streams fragmented by roads would be predictable into a trait-based approach (Leitão et al., 2018).

Headwater reaches isolated by impoundments in road-stream crossings could be compared to an isolated island, where persistence of populations tends to be dependent on species suitability to local conditions, being more influenced by random extinctions (Schlosser, 1995, 1998; Fagan, 2002). Differently, downstream lotic reaches could still be influenced by immigrants from the mainstream, so that assemblages could still sustain a higher number of species (Osborne, Wiley, 1992). Therefore, these hypotheses suggest that road-stream crossing could influence both niche- and dispersal-based processes, generating different patterns of assemblage composition and structure along the watercourse.

Land-use changes at watershed level facilitate the expansion of secondary and unofficial unpaved roads (Pocewicz, Garcia, 2016), which results in wide-spread ecological fragmentation of aquatic environment (Warren Jr., Pardew, 1998; Trombulak, Frissell, 2000; Freeman et al., 2007; Leitão et al., 2018). Based on this context, we hypothesized that the presence of anthropogenic impoundments raised from road-stream crossings, affect fish assemblages. We tested this hypothesis by evaluating the response of fish assemblages in relation to the position (upstream, impoundment and downstream) and flow characteristics (lotic or lentic) of stream reaches in fragmented streams in Eastern Amazon region. We used a multifaceted approach by considering the taxonomic and functional aspects of fish assemblages and addressed the following predictions: (1) Species and functional composition will differ in impoundments reaches in comparison to lotic reaches due to the differential influence of environmental conditions between these habitats; (2) Assemblages in downstream lotic reaches will be more diverse in species and functional groups in relation to upstream lotic and impoundment reaches, due to the relatively unmodified conditions in this habitat, associated with the connection downstream with mainstream, which, in turn, could act as a source of immigrants.

\section{MATERIAL AND METHODS}

Study Area. The study was accomplished in the northeast region of Pará State, which is one of the oldest occupation areas of eastern Amazon, where smallholder properties predominate (Watrin et al., 2009). The streams drain a flat terrain region and show sinuous unconfined channels, with high structural complexity, with habitats sequence alternating between runs, pools, and shallow water rapids. The main channel overflows in the rainy season, flooding the forested surroundings for a few months. The substrate is predominantly unconsolidated, with the accumulation of litter banks on the margins and in depositional sections (pools); roots from riparian vegetation and submerged trunks and logs compose important habitat units and are largely responsible for the 
channel structural complexity. The sampled stream segments $(n=5)$ are located at Maracanã and Marapanim river basins encompassed in the Igarapé-Açu, Marapanim and São Francisco do Pará municipalities (Fig. 1).

Sampling method. Ichthyofauna was sampled by visual census through line transect method (Sutherland, 2006). In each of the five sampled streams, three $200 \mathrm{~m}$ long transects were placed at the downstream, impounded and upstream reaches. To avoid sampling direct effects posed by roads onto the aquatic environment, the downstream and the impounded reaches line transects started at least 25 meters from the road crossing. Upstream reaches were placed in free-flowing sections, distancing $350 \mathrm{~m}$ to $820 \mathrm{~m}$ from the end of impounded sampled section $(570 \mathrm{~m} \pm 220 \mathrm{~m}$ ), where the influence of the impounded area was not clearly observed. Fishes were quantified along each line transect, considering its length of $200 \mathrm{~m}$ and a $2 \mathrm{~m}$ wide visual field. While snorkeling, the observer moved slowly to upstream (ca. $\left.4.2 \mathrm{~m} \cdot \mathrm{min}^{-1}\right)$, and collected information about richness and abundance from the observed specimens. The information about species presence and abundance gathered in situ was written on polystyrene plates during the snorkeling sessions. Between June and September 2010, 45 observation sessions were performed in the 15 stream reaches, totaling 37 hours of observations in three daily periods: 1) diurnal (between 11:00 and 14:00); 2) dusk (between 17:00 and 18:30) and 3) nocturnal (between 19:00 and 21:00).

Measurements of stream width were collected every ten meters along the transect line, depth and substrate characterization were measured at regular intervals along the

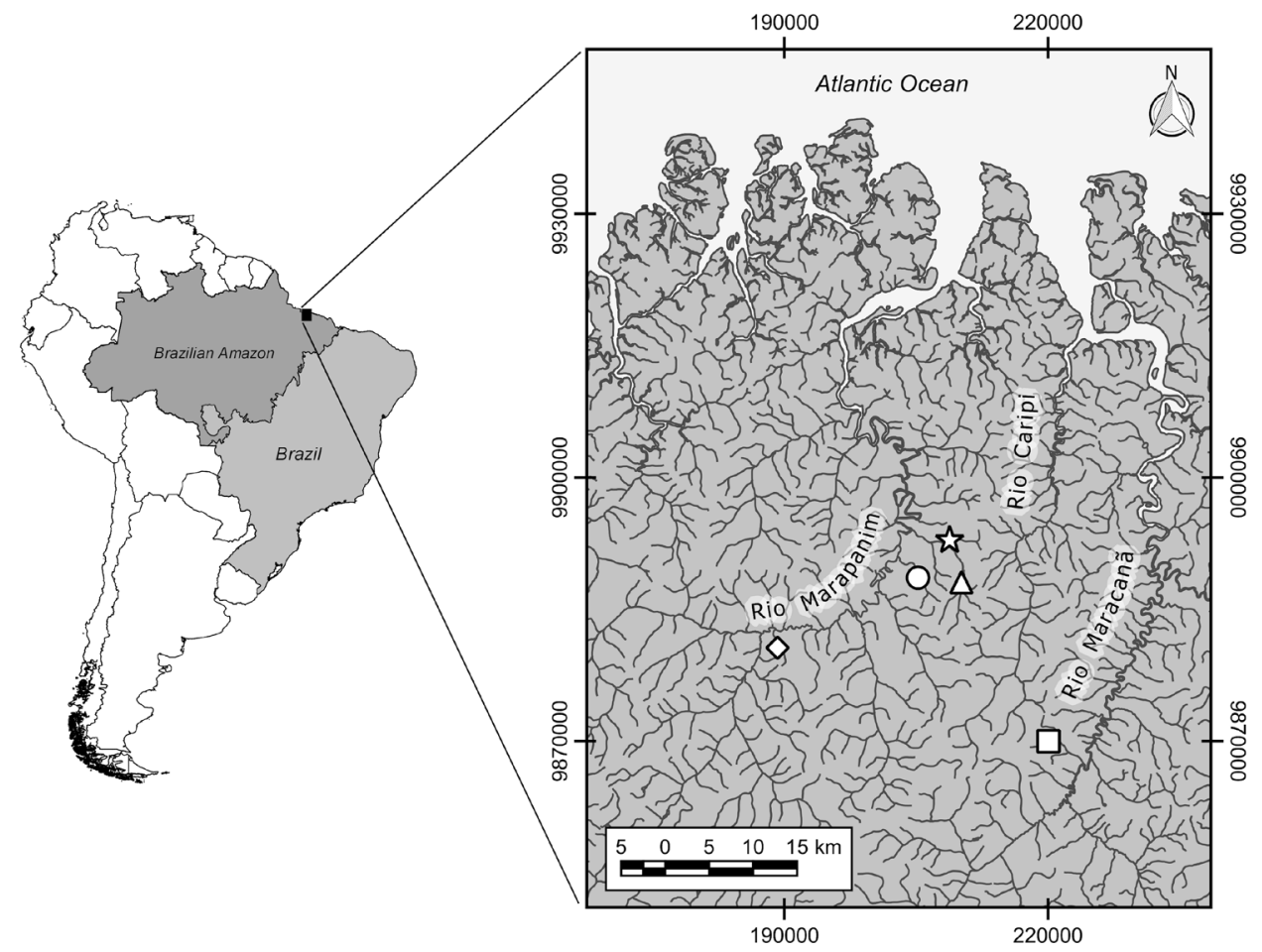

FIGURE 1 I Sampled streams location in northeastern Pará, Brazil. Circle: Igarapé Buiuna; Diamond: Igarapé Laranjal; Square: Igarapé São João; Star: Igarapé Pirapema; Triangle: Igarapé Timboteua. 
width measures. At each depth measuring point, the substrate was categorized into nine categories: (1) gravel; (2) sand; (3) clay; (4) tree trunks (large wood with diameter > $10 \mathrm{~cm}$ ); (5) coarse litter (leaves and small branches); (6) fine litter (shredded leaves); (7) roots (fine and coarse roots, from riparian vegetation); (8) macrophytes; and (9) FPOM (finely particulate organic matter). The reach area was obtained by multiplying the average width of wet channel by the length of the sampled section (Tab. 1). Since the high density of road-stream crossings in that region, we did not find five impact-free streams to use as reference sites.

Water flow was obtained by timing a semi-floating rubber ball running a defined distance. On each sampling reach, three segments $(20 \mathrm{~m})$ were selected in which the rubber ball was timed three times. After that, the average water flow at the sampling reach was obtained. The visibility was estimated as the visible extension of the transect guideline, marked meter by meter, before the beginning of each session.

Voucher specimens. Specimens of observed fish species were collected, preserved in 10\% formalin, later washed in running water and maintained in $70 \%$ ethanol. The specimens were identified using identification keys (e.g., Géry, 1977; Planquette et al., 1996; Keith et al., 2000 a,b; Sarmento-Soares, Martins-Ribeiro, 2008) and deposited at a reference collection maintained by one of the authors (PG). A representative set of the collected material was deposited at the Ichthyological Collection of the Museu Paraense Emílio Goeldi (MPEG 21370 to MPEG 21454).

Taxonomic and functional structure of assemblages. Species were grouped into functional groups according to the most frequently feeding tactic used by each species, combined with their swimming ability, spatial distribution (vertical and horizontal positions) and activity period (see table 1 in Brejão et al., 2013). These information were gathered by ad libitum snorkeling sessions (Lehner, 1996). Body size for each observed species was obtained from FishBase database (Froese, Pauly, 2019) to the functional matrix, which were categorized in three classes: 1 . Small body size (SL $<50 \mathrm{~mm}) ; 2$. Medium body size $(50 \mathrm{~mm}<\mathrm{SL}<100 \mathrm{~mm})$; and 3. Big body size $(\mathrm{SL}>100 \mathrm{~mm})$. This information was included as the abundance of each class in each sampled reach. Species richness, Shannon diversity (H'), Simpson dominance (D), and Pielou evenness (e) were obtained from a matrix containing species abundance and functional group abundance, in order to describe the taxonomic and functional structure of fish assemblages, respectively. Non-Metric Multidimensional Scaling (NMDS) ordination analysis was used to access the taxonomic and functional assemblage composition.

In order to explore the way at which species and functional composition change across stream reaches, the beta diversity was decomposed into two additive components: turnover (replacement of species or functional groups) and nestedness (dissimilarity due to differences in species or functional groups richness) based on the Sørensen dissimilarity index (Baselga, 2010). Decomposition of beta diversity was calculated between reaches of the same stream.

Data Analysis. The environmental variables and fish assemblage structure differences between the three-stream reach groups (downstream, impoundment, upstream) were tested by ANOVA, recognizing the assumption of normality and equality of variance. 
TABLE 1 I Environmental variables obtained for each one of 15 sampled stream reaches $(200 \mathrm{~m})$, the significant differences among reaches groups were highlighted in bold. Bui: Igarapé Buiuna, Lar: Igarapé Laranjal; Pir: Igarapé Pirapema; SJo: Igarapé São João; Tim: Igarapé Timboteua.

\begin{tabular}{|c|c|c|c|c|c|c|c|c|c|c|c|c|c|c|c|c|c|c|}
\hline & \multicolumn{6}{|c|}{ Upstream } & \multicolumn{6}{|c|}{ Impoundment } & \multicolumn{6}{|c|}{ Downstream } \\
\hline & Bui & Lar & Pir & SJo & Tim & Mean \pm SD & Bui & Lar & Pir & SJo & Tim & Mean \pm SD & Bui & Lar & Pir & SJo & Tim & Mean \pm SD \\
\hline Width (m) & 4.3 & 1.9 & 3.4 & 3.4 & 5.2 & $3.6 \pm 1.2$ & 4.8 & 40.0 & 3.3 & 5.0 & 6.9 & $12.0 \pm 15.7$ & 2.9 & 2.2 & 3.3 & 2.8 & 6.0 & $3.4 \pm 1.5$ \\
\hline Depth (cm)* & 37.0 & 15.5 & 51.0 & 29.0 & 58.5 & $38.2 \pm 17.2$ & 78.0 & 60.0 & 49.5 & 97.0 & 106.3 & $78.2 \pm 24.0$ & 36.0 & 32.0 & 38.0 & 47.3 & 54.0 & $41.6 \pm 9.0$ \\
\hline Area $\left(\mathrm{m}^{2}\right)$ & 74.0 & 31.0 & 102.0 & 58.0 & 117.0 & $76.4 \pm 34.3$ & 148.2 & 8000.0 & 99.0 & 116.4 & 212.5 & $1715.2 \pm 3513.2$ & 72.0 & 48.0 & 76.0 & 94.5 & 108.0 & $79.7 \pm 22.9$ \\
\hline Volume $\left(\mathrm{m}^{3}\right)$ & 27.4 & 4.8 & 52.0 & 16.8 & 68.4 & $33.9 \pm 26.0$ & 115.6 & 2400.0 & 49.0 & 112.9 & 225.8 & $580.7 \pm 1019.0$ & 25.9 & 15.4 & 28.9 & 44.7 & 58.3 & $34.6 \pm 16.9$ \\
\hline $\begin{array}{l}\text { Water flow } \\
\left(\mathrm{m} \mathrm{s}^{-1}\right)^{*}\end{array}$ & 0.2 & 0.1 & 0.2 & 0.3 & 0.4 & $0.2 \pm 0.1$ & 0.1 & 0.0 & 0.2 & 0.0 & 0.2 & $0.1 \pm 0.1$ & 0.4 & 0.2 & 0.3 & 0.4 & 0.4 & $0.3 \pm 0.1$ \\
\hline Gravel (\%) & 0.0 & 0.0 & 0.0 & 0.0 & 0.0 & 0 & 0.0 & 0.0 & 0.0 & 7.4 & 0.9 & $1.7 \pm 3.2$ & 3.4 & 0.0 & 0.0 & 0.0 & 17.1 & $4.1 \pm 7.4$ \\
\hline Sand (\%) & 17.3 & 6.5 & 26.6 & 73.8 & 53.7 & $35.6 \pm 27.6$ & 4.0 & 0.0 & 2.9 & 25.9 & 18.5 & $10.3 \pm 11.3$ & 44.4 & 4.4 & 50.5 & 40.8 & 65.8 & $41.2 \pm 22.7$ \\
\hline Clay (\%) & 0.9 & 0.0 & 0.0 & 0.0 & 0.0 & $0.2 \pm 0.4$ & 0.0 & 0.0 & 2.9 & 0.0 & 0.9 & $0.8 \pm 1.3$ & 0.9 & 1.1 & 0.0 & 0.0 & 0.9 & $0.6 \pm 0.5$ \\
\hline $\begin{array}{r}\text { Tree trunks or } \\
\text { branches (\%) }\end{array}$ & 10.0 & 3.7 & 2.7 & 1.9 & 7.4 & $5.1 \pm 3.5$ & 11.1 & 30.0 & 11.5 & 7.4 & 5.6 & $13.1 \pm 9.8$ & 7.7 & 4.4 & 13.8 & 9.7 & 11.1 & $9.3 \pm 3.5$ \\
\hline $\begin{array}{r}\text { Coarse litter } \\
(\%)\end{array}$ & 57.3 & 62.0 & 41.6 & 16.8 & 13.9 & $38.3 \pm 22.3$ & 42.4 & 0.0 & 44.2 & 0.0 & 41.7 & $25.7 \pm 24.3$ & 27.4 & 47.3 & 18.4 & 34.0 & 13.7 & $28.1 \pm 13.3$ \\
\hline Fine litter (\%) & 7.3 & 22.2 & 16.8 & 3.7 & 16.7 & $13.3 \pm 7.6$ & 30.3 & 0.0 & 14.4 & 44.4 & 19.4 & $21.7 \pm 16.7$ & 0.0 & 22.0 & 6.4 & 6.8 & 2.6 & $7.6 \pm 8.5$ \\
\hline Roots (\%) & 5.5 & 0.9 & 4.4 & 0.9 & 27.8 & $7.9 \pm 11.3$ & 5.1 & 0.0 & 2.9 & 1.9 & 9.3 & $3.8 \pm 3.6$ & 14.5 & 17.6 & 7.3 & 3.9 & 4.3 & $9.5 \pm 6.2$ \\
\hline $\begin{array}{r}\text { Macophytes } \\
(\%)\end{array}$ & 0.0 & 0.0 & 0.0 & 0.9 & 5.6 & $1.30 \pm 2.4$ & 5.1 & 10.0 & 2.9 & 13.0 & 3.7 & $6.9 \pm 4.4$ & 1.7 & 3.3 & 0.0 & 0.0 & 0.0 & $1.0 \pm 1.5$ \\
\hline FPOM (\%) & 1.8 & 4.6 & 8.0 & 1.9 & 0.0 & $3.3 \pm 3.1$ & 2.0 & 60.0 & 18.3 & 0.0 & 0.0 & $16.1 \pm 25.7$ & 0.0 & 0.0 & 3.7 & 4.9 & 0.0 & $1.7 \pm 2.4$ \\
\hline $\begin{array}{r}\text { Substrate } \\
\text { diversity (H') }\end{array}$ & 1.3 & 1.1 & 1.5 & 0.9 & 1.5 & $1.3 \pm 0.3$ & 1.5 & 0.9 & 1.6 & 1.5 & 1.6 & $1.4 \pm 0.3$ & 1.4 & 1.4 & 1.4 & 1.4 & 1.3 & $1.4 \pm 0.0$ \\
\hline $\begin{array}{r}\text { Minimum } \\
\text { temperature } \\
\left({ }^{\circ} \mathrm{C}\right)\end{array}$ & 26.0 & 25.5 & 25.0 & 25.5 & 25.0 & $25.4 \pm 0.4$ & 26.0 & 30.0 & 25.0 & 26.0 & 25.5 & $26.5 \pm 2.0$ & 26.0 & 27.0 & 25.0 & 26.0 & 25.0 & $25.8 \pm 0.8$ \\
\hline $\begin{array}{r}\text { Maximum } \\
\text { temperature } \\
\left({ }^{\circ} \mathrm{C}\right)\end{array}$ & 26.0 & 25.5 & 26.0 & 26.0 & 26.0 & $25.9 \pm 0.2$ & 27.5 & 31.5 & 26.0 & 27.0 & 26.0 & $27.6 \pm 2.3$ & 27.0 & 27.0 & 26.0 & 26.5 & 25.0 & $26.3 \pm 0.8$ \\
\hline Visibility (m) & 2.0 & 3.0 & 1.5 & 5.0 & 1.2 & $2.5 \pm 1.5$ & 1.6 & 3.0 & 2.0 & 3.0 & 1.0 & $2.1 \pm 0.9$ & 2.0 & 1.5 & 1.3 & 2.0 & 1.2 & $1.6 \pm 0.4$ \\
\hline
\end{tabular}


To describe and evaluate the impoundment effect on the taxonomic and functional composition, the data of species abundance and functional group abundance across the three groups of reaches were analyzed by using a Non-Metric Multidimensional Scaling (NMDS) based on Bray-Curtis similarity index (Clarke, Warwick, 2001), complemented with an Analysis of Similarity (ANOSIM), with a 5\% significance level. The significant environmental variables $(\mathrm{p}<0.05)$ related to taxonomic and functional composition were identified and plotted by using the envfit function. All statistical analyses were performed in R (R Core Team, 2019) using Vegan (Oksanen et al., 2019) and MASS (Venables, Ripley, 2002) packages.

\section{RESULTS}

Stream reaches differed only in stream depth $(\mathrm{p}=0.006$, Fig. $2 \mathrm{~A})$ and water flow $(\mathrm{p}$ $=0.01$, Fig. 2B). Upstream and downstream reaches were shallower than impounded reaches $(p=0.01)$; downstream reaches have faster water current than impounded reaches $(p=0.01)$, no significant differences were found between upstream and downstream reaches. No differences related to the others environmental descriptors among the three reach groups (upstream, impoundment and downstream) were found.

A total of 7,834 specimens from 65 species (Tab. S1) was sampled in the 15 stream reaches. These species were grouped in 18 functional trophic groups, according to their feeding tactics, water column occupation and period of activity.

A

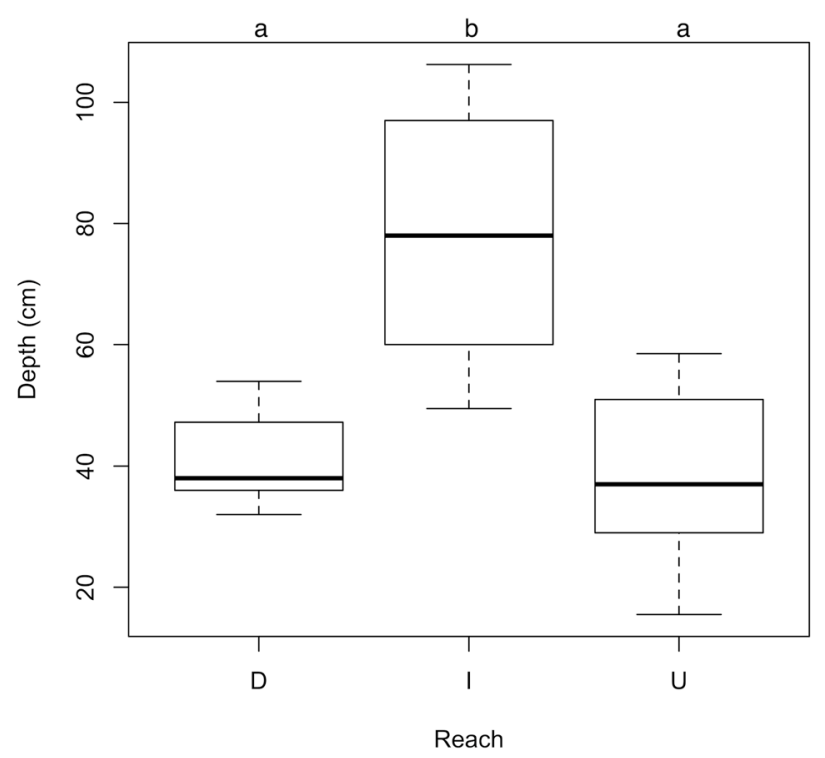

B

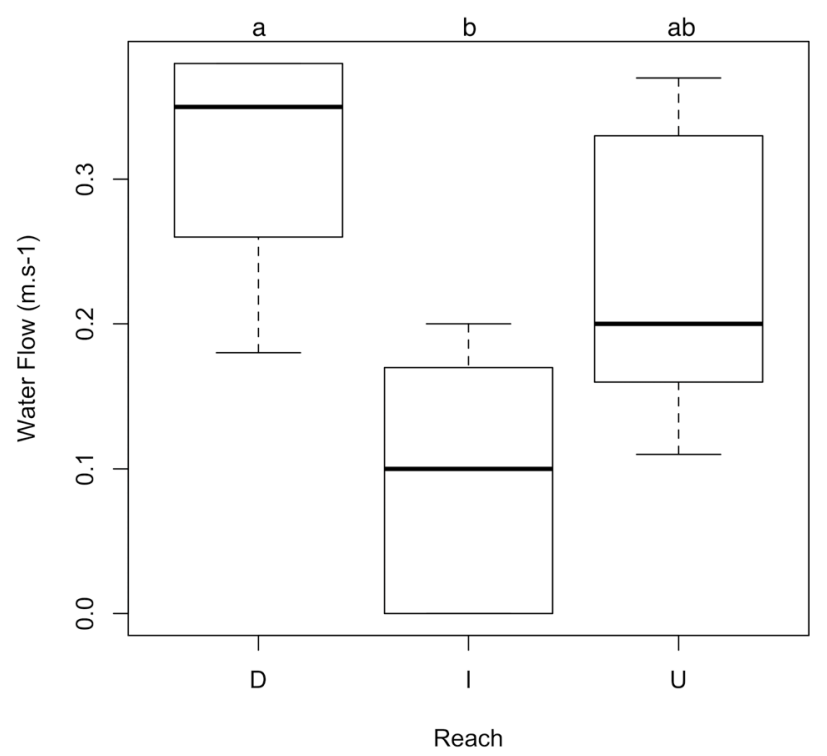

FIGURE 2 I ANOVA results for environmental significant differences among stream reach groups. A. Depth; B. Water flow. D: Downstream reaches from impoundments; I: Impounded reaches; U: Upstream reaches from impoundments. 
The taxonomic and functional composition at impounded reaches differed from lotic reaches, but there was no difference between the lotic reaches (ANOSIM Taxonomic Composition: upstream $v$ s. impoundment, $\mathrm{p}=0.022$; upstream $v$ s. downstream, $\mathrm{p}=0.312$; impoundment $v s$. downstream, $\mathrm{p}=0.007$; ANOSIM Functional Composition: upstream vs. impoundment, $\mathrm{p}=0.032$; upstream vs. downstream, $\mathrm{p}=0.243$; impoundment $v$ s. downstream, $\mathrm{p}=0.006$ ) (Figs. $3 \mathrm{~A}-\mathrm{B}$ ). The functional composition differences were mainly related to the functional trophic groups, the body size was not important in this separation of the groups.

The changes in taxonomic and functional composition among stream reaches (i.e., beta diversity) were associated with both turnover and nestedness. The turnover had a higher contribution for the total beta diversity between stream reaches, except between upstream and downstream reaches in relation to functional composition (Fig. 4). In addition, the nestedness component had a lower contribution for beta diversity of species and functional groups between upstream-impoundment reaches relative to impoundment-downstream and upstream-downstream (Fig. 4).

Diurnal species and functional groups associated with slower and deeper environments were grouped at impounded reaches, especially Cichlidae (e.g., Heros efasciatus and Satanoperca jurupari), small species of Curimatidae (e.g., Curimatopsis cf. cryptica), Lebiasinidae (e.g., Nannostomus eques), and large pelagic predators (e.g., Acestrorhynchus cf. falcatus), belonging to diggers, picker and browsers, mudeaters, diurnal surface pickers, and pursuit predators functional groups (Figs. 3A-B). Differently, species and functional groups presenting twilight-night habits were grouped at lotic reaches, linked to shallow environments with high water flow, belonging mainly to Siluriformes (e.g., Mastiglanis asopos, Helogenes marmoratus, Denticetopsis epa, Tatia gyrina, Rineloricaria heteroptera, and Farlowella amazonum), Gymnotiformes (e.g., Hypopygus lepturus and Gymnorhamphichthys rondoni), Crenuchidae (Characidium fasciatus) and larger species of Characidae (e.g., Bryconops melanurus and Moenkhausia comma), belonging to sit-and-wait predators, crepuscular to nocturnal drift feeders, grazers, invertebrate pickers and diurnal channel drift feeders functional groups (Figs. 3A-B).

Nine species were exclusively observed in downstream lotic reaches (e.g., Bryconamericus cf. diaphanus, Charax cf. metae, Bunocephalus coracoideus, Corydoras cf. acutus, Gymnotus coropinae, Hypopygus lepturus, Microsternarchus bilineatus, and Apteronotus albifrons), and eight species, which were exclusively observed in lotic reaches, presented higher abundance in downstream, when compared to upstream lotic reaches (Hoplias cf. malabaricus, Denticetopsis cf. epa, Helogenes marmorauts, Potamoglanis hasemani, Farlowella cf. amazonum, Pimelodella sp., Sternopygus macrurus, and Steatogenys duidae) (Tab. S1). Regarding functional groups, grazers, sit-and-wait predators and crepuscular to nocturnal bottom predators and crepuscular to nocturnal drift feeders presented higher abundance in downstream lotic reaches (Tab. S1).

Regarding the assemblage structure, downstream reaches have higher taxonomic and functional diversity, in relation to upstream and impounded reaches $(p=0.01$, Figs. $5 \mathrm{~A}-\mathrm{B})$, which, in turn, have similar patterns. No differences were found for the other assemblage descriptors (Simpson dominance and Pielou evenness) ( $p>0.148$ ). 
A

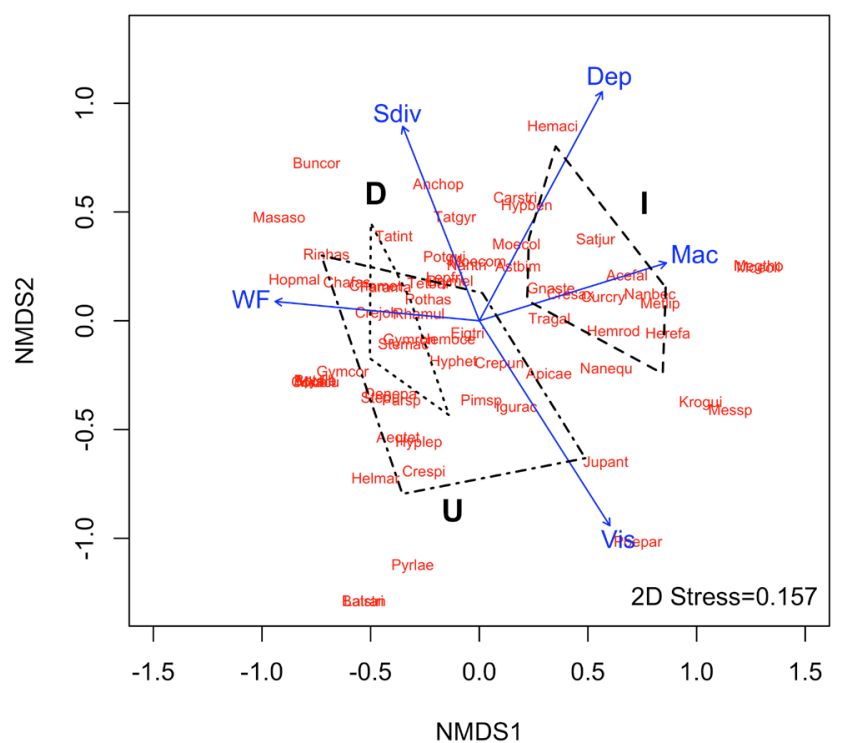

B

Functional composition

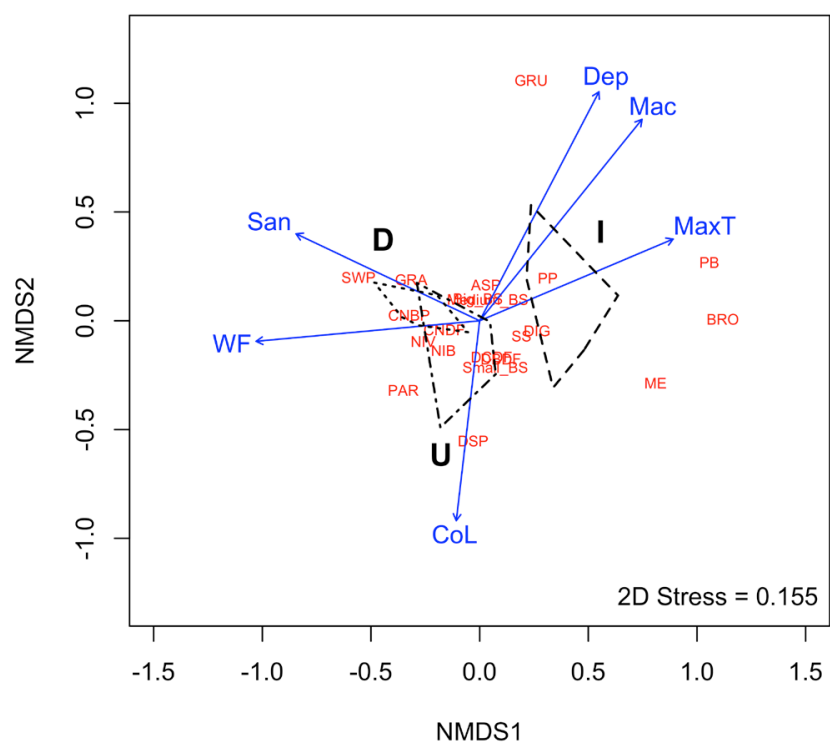

FIGURE 3 । NMDS results for fish assemblage composition in northeastern Amazonian streams. A. Taxonomic composition. Fitted variables: Dep: average depth; Mac: macrophytes; Sdiv: substrate diversity; Vis: visibility; WF: average water flow. B. Functional composition. Fitted variables: CoL: coarse litter; Dep: average depth; Mac: macrophytes; MaxT: maximum temperature; San: sand; WF: average water flow. Dot-dashed polygon: Upstream reaches (U); Dotted polygon: Downstream reaches (D); Dashed polygon: Impounded reaches (I). For species and functional groups codes, see Tab. S1.

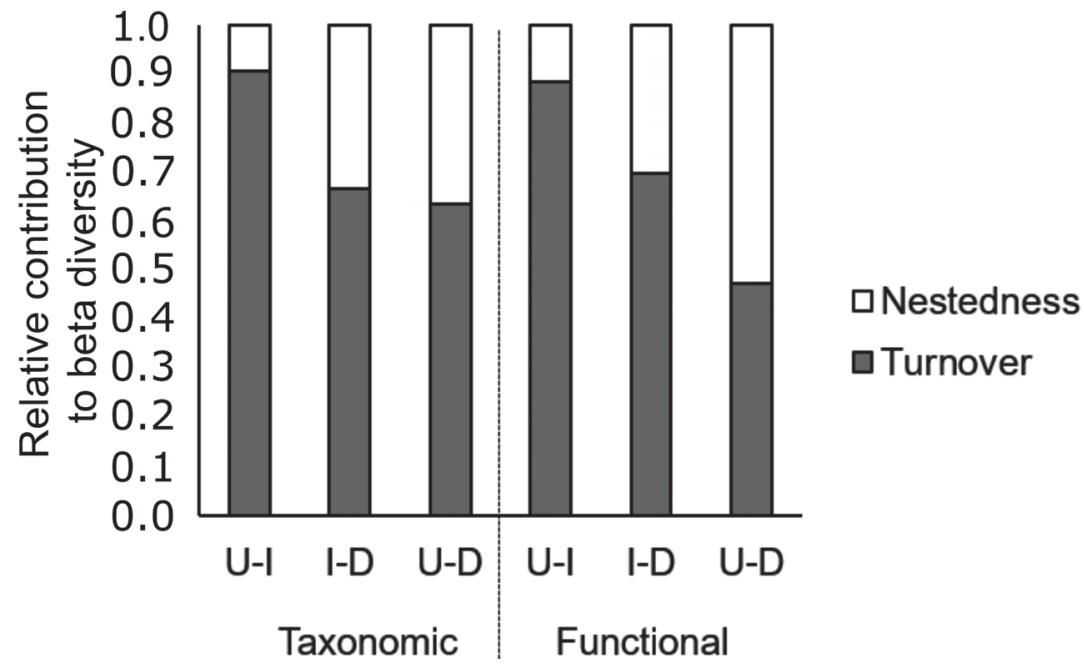

FIGURE 4 I Relative contribution of turnover and nestedness component to total beta diversity obtained after averaging pairwise dissimilarities (Sørensen index) between stream reaches at each stream. D: Downstream reaches from impoundments; I: Impounded reaches; U: Upstream reaches from impoundments. 
A

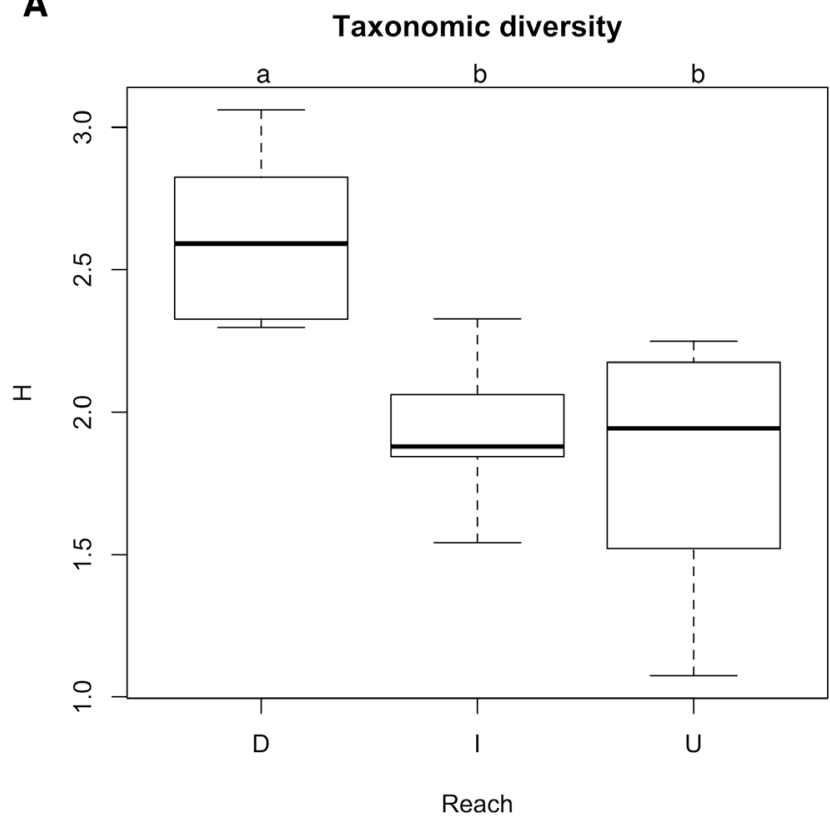

B

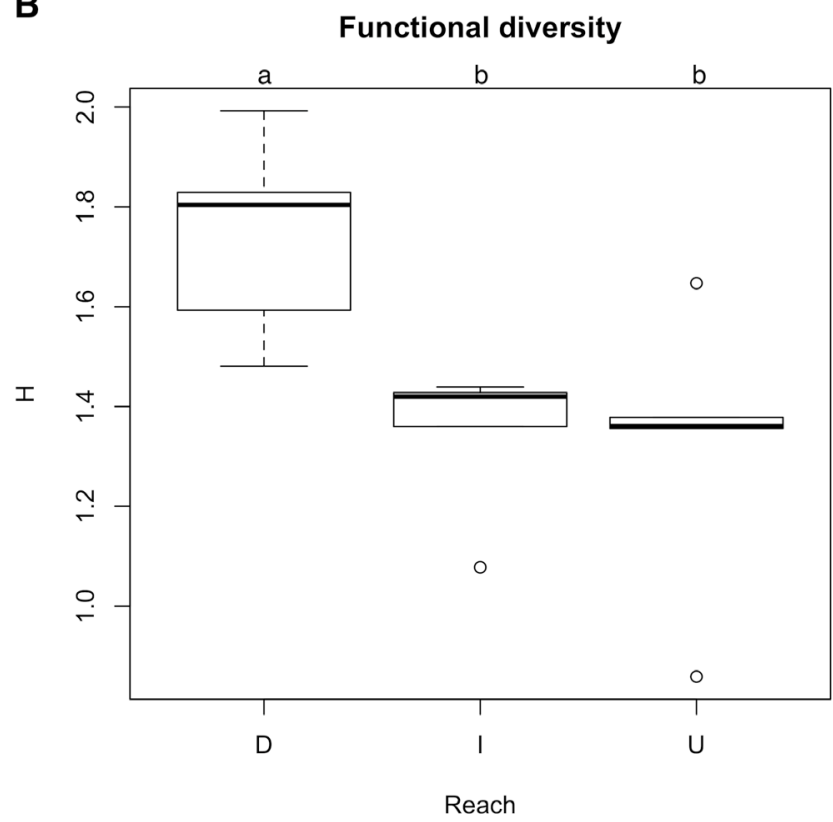

FIGURE 5 I ANOVA results for assemblage structure in northeastern Amazonian streams among stream reach groups. A. Taxonomic structure; B. Functional structure. D: Downstream reaches from impoundments; I: Impounded reaches; U: Upstream reaches from impoundments.

\section{DISCUSSION}

We tested the hypothesis that the presence of anthropogenic impoundments raised from road-stream crossings should affect fish assemblages. Our data show that impoundments are environmentally different from lotic reaches influencing the taxonomic and functional structure of fish assemblages. Upstream and downstream lotic reaches showed similar species/functional composition while they were different from impounded reaches, evidencing the influence of differential habitat constraints between lentic and lotic habitats. Furthermore, the damming effects seem to reverberate to the lotic reaches upstream from impoundments, which presented lower diversity than the lotic reaches downstream from impoundments, probably due to dispersal limitation from lower land species. These results suggest that poorly installed structures in road stream crossing influence aquatic assemblage structure mediated by their influences in habitat structure and connectivity. Despite the streams from this region being under a seasonal flooding regime (Igapó), the road-stream crossing embankment per se also constitute a barrier to the continuity of this natural process, interrupting the connection between the downstream lotic and the impounded reaches above the road, affecting fish movement (Fullerton et al., 2010).

The increased width and volume of impoundment reaches is followed by the development of pelagic and benthic areas in these newly formed lotic habitats. This change, coupled with the water flow reduction and canopy opening caused by the death of riparian zone trees allows the proliferation of macrophytes, especially Nymphaea spp. and Eleocharis spp. In natural conditions, the streams from the studied region have 
weakly confined channels and their beds present complex conformation with intense lateral interactions with the floodplain (Brejão et al., 2013). Our field observations, confirmed on Google Earth imagery, indicate that these impoundments, with rather low heads (< 3 meters), can flood at least $1 \mathrm{~km}$ upstream from the road crossing, which represents from 25 to 500 times the mean width of the studied environments.

The stream impounding alters the system base level, promoting the raising of water level associated with the reduction of water flow, drowning the riparian forest permanently. Hence, this permanent root drowning leads the trees to languish and die (White, 2007), opening the riparian canopy, allowing the light input. The reduction of water flow increase the organic matter residence time, which, associated with the light intake increasing could support an autotrophic chain, interfering on the fluvial continuum (Vannote et al., 1980) and the spatial and environmental dynamics of the aquatic ecosystem upstream the crossing (Ward, Stanford, 1983) by permanently flooding a large portion of streams floodplains.

The species that are most successful in colonization after the formation of a reservoir are those adapted to the new environments created, such as submerged logs, macrophyte banks and extensive pelagic areas (Fernando, Holčík, 1982). In addition, species that do not migrate (sedentary species) tend to be more successful in colonizing the reservoirs as they generally have fewer demands on the complex spatial dynamics of their life cycle (Schlosser, 1995; Agostinho et al., 1999; Agostinho et al., 2008). In small-head dams, which the dimensions are more comparable with this study, the assemblages from impounded environments are characterized by species related to deeper and slowflowing water habitats, while at the lotic downstream reaches, species related to shallow and swift-flowing habitats are, usually, more common (Gillette et al., 2005). In fact, the replacement of species was the main mechanism driving species and functional group differentiation between impoundment reaches and lotic reaches. Our results support these expectations, as the taxonomic and functional composition of impounded reaches differed from lotic ones in a predictable way.

In a recent review about the impacts of hydroelectric dams on fishes and fisheries in tropical rivers, Arantes et al. (2019) pointed out that shifts in assemblage composition and structure as one of the patterns frequently observed due to river damming, and they also identified that the most vulnerable species have functional traits associated with flowing water, flow pulses, and habitat complexity and connectivity. In our study we also observed these shifts comparing lotic and lentic reaches, since Cichlidae species that forage by digging the streambed (Satanoperca jurupari) or by browsing portions of periphyton adhered on macrophytes and logs, and picking suspended particles (Heros efasciatus); Curimatidae foraging organic matter on streambed; Lebiasinidae species, that are picking particles at surface and adhered macrophytes; and large bodied and visual oriented predators, like Acestrorhynchus cf. falcatus, were favored in impoundments, probably due the higher availability of these food items and the expansion of some habitat compartments in this novel environments. Otherwise, nocturnal, sensorial oriented species like invertebrate pickers (Gymnotiformes), probing their preys using their electric fields at night; Siluriformes species, picking food items drifting at streamflow (Auchenipteridae and Cetopsidae), actively hunting on streambed (Heptapteridae) or by sitting and wait (Mastiglanis asopos); and visual orientated diurnal species that forages by picking food items drifting at streamflow (e.g., Bryconops melanurus and Moenkhausia 
comma) or by sitting-and-wait (Characidium fasciatus) were strongly associated with the lotic environments.

Despite similarities between upstream and downstream reaches in relation to species and functional composition, downstream reaches were more diverse than impoundment and upstream reaches, as evidenced by Shannon diversity results. As upstream lotic reaches show lower diversity than downstream lotic reaches, despite their environmental similarity, we could suggest that the environment does not explain these differences. While downstream reaches would be more influenced by mass effect due to the proximity from a mainstream source, dispersal from downstream to upstream reaches would be interrupted by the impoundment. As a consequence, downstream reaches would receive more immigrants and consequently maintain higher diversity via dispersal, suggesting that these road-stream crossings are barriers to fish movement, restricting their capacity to access the upstream habitats (Morita, Yamamoto, 2002). These interpretations are consistent with the higher contribution of nestedness component (i.e., richness differences) for the beta diversity that we found between upstream and downstream reaches mainly in relation to functional groups. In fact, we found higher abundance of functional groups composed by benthic and nektobenthic species (grazers, sit-and-wait predators, and crepuscular to nocturnal bottom) in downstream reaches when compared to impounded and upstream reaches, the species into these groups probably did not have the ability to transpose the road crossing barrier. Moreover, upstream assemblages would also be more exposed to extinction, as limited immigration could not avoid extinction of declining populations via rescue effect (Brown, Kodric-Brown, 1977) and depending on the time since isolation (Morita, Yamamoto, 2002).

In the studied region, road-stream crossings are commonly made adding a subdimensioned culvert with diameter ranging from $0.4 \mathrm{~m}$ to $1.1 \mathrm{~m}$, placed in stream valleys with width ranging from $70 \mathrm{~m}$ to $150 \mathrm{~m}$, over the streambed and barred soil to prepare the embankment for the road. These poorly designed and installed culverts create a height gap, rise the water flow inside the structure, modify the substrate, alter the light input into the culverts and its surroundings, and, as observed in studied region, creates unsuitable habitats close to the downstream culvert outlet, like plunge pools (Powers, Orsborn, 1985; Warren Jr., Pardew, 1998; Wellman et al., 2000; Bouska, Paukert, 2010; Nislow et al., 2011; MacPherson et al., 2012; Mariano et al., 2012; Makrakis et al., 2012). These features act as a barrier isolating the downstream lotic reaches from impounded reaches and hindering fish dispersion to the upstream lotic environment. These environmental perturbations can be compared to low-head dams and beaver ponds from temperate systems, where higher species richness in lotic reaches is commonly documented, mostly in reaches downstream from impounded areas (Schlosser, Kallemeyn, 2000; Helms et al., 2011). In summary, we showed that the responses of fish assemblages to impoundment raised from road-stream crossing are predictable. Species composition varies according to lentic/lotic conditions, which can be explained by differential performance of species mediated by their traits. Moreover, impoundments can also act as a barrier, affecting immigration and extinction at upstream reaches. Therefore, our study provides evidence that niche- and dispersalbased processes drive community assembly in streams disturbed by impoundments in road-stream crossings. 
The hydrological network fragmentation and lentification, which consist in transformation of the habitat characteristic of streams and rivers in the direction from lotic to lentic (Sabater, 2008), of water courses, when considered in larger scales, could drive an important beta diversity loss. Since stream lentification standardizes the stream environmental conditions, leading to the selection and predominance of a restrict set of species/functional groups adapted to those novel habitats, and interrupt the immigration processes to upstream lotic reaches. In an applied perspective, our results suggest that the simple placement of culverts on the streambed, although cheaper, is not ecologically functional. Therefore, it is important to establish standards and define best practices for constructing, installing and managing culverts in the Brazilian Amazon, in order to allow the free flow of water bodies, respecting the regional hydrological dynamics and reduce the inevitable impacts over fish assemblages.

\section{ACKNOWLEDGEMENTS}

The authors wish to acknowledge Embrapa Amazônia Oriental for providing logistics for the fieldwork, CNPq (Process number 574.648/2008-9) for financial support, and FAPESPA for GB study fellowship (Grant 020/2008). FBT is supported by CNPq (302158/2015-4) and GB by FAPESP (2018/11954-9). Fish sampling was possible due to the permit 22111-1 issued by ICMBio to PG. The authors are thankful to Dr. Anderson Ferreira for his valuable help at fieldwork and for insightful discussions on fish feeding behavior.

\section{REFERENCES}

\section{- Agostinho AA, Miranda LE, Bini LM, Gomes LC, Thomaz SM, Suzuki HI. Patterns of colonization in Neotropical reservoirs, and prognoses on aging. In: Tundisi JG, Strakaškraba M, editors. Theoretical reservoir ecology and its aplication. 2nd ed. São Carlos: Backhuys Publishers; 1999. p.227-64.}

- Agostinho AA, Pelicice FM, Gomes LC. Dams and the fish fauna of the Neotropical region: impacts and management related to diversity and fisheries. Braz J Biol. 2008; 68(4 Suppl):1119-32. https://doi. org/10.1590/S1519-69842008000500019

- Arantes CC, Fitzgerald DB, Hoeinghaus DJ, Winemiller KO. Impacts of hydroelectric dams on fishes and fisheries in tropical rivers through the lens of functional traits. Curr Opin Environ Sustain. 2019; 37:28-40. https://doi. org/10.1016/j.cosust.2019.04.009
- Baselga A. Partitioning the turnover and nestedness components of beta diversity. Glob Ecol Biogeogr Let. 2010; 19(1):134-43. https://doi.org/10.1111/j.14668238.2009.00490.x

- Benítez-López A, Alkemade R, Verweij PA. The impacts of roads and other infrastructure on mammal and bird populations: A meta-analysis. Biol Conserv. 2010; 143(6):1307-16. https://doi. org/10.1016/j.biocon.2010.02.009

- Bouska WW, Paukert CP. Road crossing designs and their impact on fish assemblages of Great Plains streams. Trans Am Fish Soc. 2010; 139(1):214-22. https:// doi.org/10.1577/T09-040.1

- Brejão GL, Gerhard P, Zuanon J. Functional trophic composition of the ichthyofauna of forest streams in eastern Amazon. Neotrop Ichthyol. 2013; 11(2):361-73. https://doi.org/10.1590/S167962252013005000006 
- Brown JH, Kodric-Brown A. Turnover rates in insular biogeography: Effect of Immigration on Extinction. Ecology. 1977; 58(2):445-49. https://doi. org/10.2307/1935620

- Clarke KR, Warwick RM. Changes in marine communities: an approach to statistical analysis and interpretation. PRIMER-E. 2001. 172p.

- Develey PF, Stouffer PC. Effects of roads on movements by understory birds in mixed-species flocks in Central Amazonian Brazil. Conserv Biol. 2001; 15(5):1416-22. https://www.jstor.org/stable/3061497?seq=1

- Fagan WF. Connectivity, fragmentation, and extinction risk in dentritic metapopulations. Ecology. 2002; 83(12):3243-49. https://doi.org/10.1890/00129658(2002)083[3243:CFAERI]2.0.CO;2

- Fernando $\mathbf{C H}$, Holčík J. The nature of fish communities: A factor influencing the fishery potential and yields of tropical lakes and reservoirs. Hydrobiologia. 1982; 97(2):127-40. https://doi.org/10.1007/ BF00011966

- Froese R, Pauly D. FishBase. World Wide Web electronic publication [Internet]. 2019. Available from: www.fishbase.org.

- Forman RTT, Alexander LE. Roads and their major ecological effects. Annu Rev Ecol Syst. 1998; 29(1):207-31. https://doi. org/10.1146/annurev.ecolsys.29.1.207

- Freeman MC, Pringle CM, Jackson CR. Hydrologic Connectivity and the Contribution of stream headwaters to ecological integrity at regional scales. J Am Water Resour Assoc. 2007; 43(1):5-14. https://doi.org/10.1111/j.17521688.2007.00002.x

- Fullerton AH, Burnett KM, Steel EA, Flitcroft FL, Pess GR, Feist BE, Torgersen CE, Miller DJ, Sanderson SL. Hydrological connectivity for riverine fish: measurement challenges and research opportunities. Freshw Biol. 2010; 55(11):2215-37. https://doi.org/10.1111/ j.1365-2427.2010.02448.x

- Géry J. Characoids of the world. Neptune City: TFH Publications. 1977.

- Gillette PD, Tiemann JS, Edds DR, Wildhaber ML. Spatiotemporal patterns of fish assemblage structure in a river impouded by low-head dams. Copeia. 2005; 2005(3):539-49. https://doi.org/10.1643/CE04-135R2
- Haskell DG. Effects of forest roads on macroinvertebrate soil fauna of the Southern Appalachian Mountains. Conserv Biol. 2000; 14(1):57-63. https://doi. org/10.1046/j.1523-1739.2000.99232.x

- Helms BS, Werneke DC, Gangloff MM, Hartfield EE, Feminella JW. The influence of low-head dams on fish assemblages in streams across Alabama. J North Am Benthol Soc. 2011; 30(4):1095-106. https:// doi.org/10.1899/10-093.1

- Hortal J, de Bello F, Diniz-Filho JAF, Lewinsohn TM, Lobo JM, Ladle RJ. Seven shortfalls that beset large-scale knowledge of biodiversity. Annu Rev Ecol Evol Syst. 2015; 46(1):523-49. https://doi.org/10.1146/ annurev-ecolsys-112414-054400

- Keck BP, Marion ZH, Martin DJ, Kaufman JC, Harden CP, Schwartz JS et al. Fish functional traits correlated with environmental variables in a temperate biodiversity hotspot. PLoS One. 2014; 9(3):e93237. https://doi.org/10.1371/journal. pone.0093237

- Keith P, Le Bail PY, Planquette P. Atlas des poissons d'eau douce de Guyane. Tome 2, fascicule I: Batrachoidiformes, Mugiliformes, Beloniformes, Cyprinodondiformes, Synbranchiformes, Percifomes, Pleuronectiformes, Tetraodontiformes. Paris: Publications scientifiques du Muséum National d'Histoire Naturelle. 2000a.

- Keith P, Le Bail PY, Planquette P. Atlas des poissons d'eau douce de Guyane. Tome 2, fascicule II: Siluriformes. Paris: Publications scientifiques du Muséum National d'Histoire Naturelle. 2000b.

- Lake PS. Disturbance, patchiness, and diversity in streams. J North Am Benthol Soc. 2000; 19(4):573-92. https://doi. org/10.2307/1468118

- Laurance WF, Goosem M, Laurance SGW. Impacts of roads and linear clearings on tropical forests. Trends Ecol Evol. 2009; 24(12):659-69. https://doi.org/10.1016/j. tree.2009.06.009

- Lehner PN. Handbook of ethological methods. 2nd ed. Cambridge: Cambridge University Press; 1996.

- Leitão RP, Zuanon J, Mouillot D, Leal CG, Hughes RM, Kaufmann PR et al. Disentangling the pathways of land use impacts on the functional structure of fish assemblages in Amazon streams. Ecography. 2018; 41(1):219-32. https://doi. org/10.1111/ecog.02845 
- MacPherson LM, Sullivan MG, Foote L, Stevens CE. Effects of culverts on stream fish assemblages in the Alberta Foothills. N Am J Fish Manag. 2012; 32(3): 480-90. https://doi.org/10.1080/02755947.2012.68 6004

- Makrakis S, Castro-Santos T, Makrakis MC, Wagner RL, Adames MS. Culverts in paved roads as suitable passages for Neotropical fish species. Neotrop Ichthyol. 2012; 10(4):763-70. https://doi.org/10.1590/ S1679-62252012000400009

- Mariano JR, Makrakis MC, Kashiwaqui EAL, Celestino EF, Makrakis S. Longitudinal habitat disruption in Neotropical streams: Fish assemblages under the influence of culverts. Neotrop Ichthyol. 2012; 10(4):771-84. https://doi. org/10.1590/S1679-62252012000400010

- Morita K, Yamamoto S. Effects of habitat fragmentation by damming on the persistence of stream dwelling charr populations. Conserv Biol. 2002; 16(5):1318-23. https://doi.org/10.1046/ j.1523-1739.2002.01476.x

- Nislow KH, Hudy M, Letcher BH, Smith EP. Variation in local abundance and species richness of stream fishes in relation to dispersal barriers: Implications for management and conservation. Freshw Biol. 2011; 56(10):2135-44. https://doi. org/10.1111/j.1365-2427.2011.02634.x

- Oksanen J, Blanchet FG, Friendly M, Kindt R, Legendre P, McGlinn D et al. vegan: Community Ecology Package. R package version 2.5-6 [Internet]. 2019. Available from: https://CRAN.R-project.org/ package $=$ vegan

- Osborne LL, Wiley MJ. Influence of tributary spatial position on the structure of warmwater fish communities. Can J Fish Aquat Sci. 1992; 49(4):671-81. https://doi. org/10.1139/f92-076

- Planquette P, Keith P, Le Bail PY. Atlas des poissons d'eau douce de Guyane. Tome I. Paris: Publications scientifiques du Muséum National d'Histoire Naturelle. 1996.

- Pocewicz A, Garcia E. Deforestation facilitates widespread stream habitat and flow alteration in the Brazilian Amazon. Biol Conserv. 2016; 203:252-59. https://doi. org/10.1016/j.biocon.2016.09.032
- Powers PD, Orsborn JF. Analysis of barries to upstream fish migration: An investigation of the physical and biological conditions affecting fish passage success at culverts and waterfalls. Final Report 1984 (Project No. 82-14). Portland: Department of Energy, Bonneville Power Administration, Division of Fish and Wildlife. 1985. https://doi. org/10.2172/917018

- R Development Core Team. R: a language and environment for statistical computing. Vienna, Austria: R Foundation for Statistical Computing. 2019. Available from: http://www.R-project.org/

- Rolls RJ, Srewart-Koster B, Ellison T, Faggotter S, Roberts DT. Multiple factors determine the effect of anthropogenic barriers to connectivity on riverine fish. Biodivers Conserv. 2014; 23:2201-20. https://doi.org/10.1007/s10531-014-0715-5

- Sabater S. Alterations of the global water cycle and their effects on river structure, function and services. Freshw Rev. 2008; 1(1):75-88. https://doi.org/10.1608/FRJ-1.1.5

- Sarmento-Soares LM, Martins-Ribeiro RF. 2008 A systematic revision of Tatia (Siluriformes: Auchenipteridae: Centromochlinae). Neotrop Ichthyol. 2008; 6(3):494-542. https://doi.org/10.1590/S167962252008000300022

- Schlosser IJ, Kallemeyn LW. Spatial variation in fish assemblages across a beaver-influenced successional landscape. Ecology. 2000; 81(5):1371-82. https://doi. org/10.1890/0012-9658(2000)081[1371:SVIF AA]2.0.CO;2

- Schlosser IJ. Dispersal, boundary processes, and trophic-level interactions in streams adjacent to beaver ponds. Ecology. 1995; 76(3):908-25. https://doi. org/10.2307/1939356

- Schlosser IJ. Fish recruitment, dispersal, and trophic interactions in a heterogeneous lotic environment. Oecologia. 1998; 113(2):260-68. https://doi. org/10.1007/s004420050377

- Spellerberg IF. Ecological effects of roads and traffic: a literature review. Glob Ecol Biogeogr Let. 1998; 7(5):317-33. https://doi. org/10.2307/2997681

- Sutherland WJ. Ecological census techniques: a handbook. 2nd ed. Cambridge: Cambridge University Press; 2006. https://doi.org/10.1017/ CB09780511790508 
- Trombulak SC, Frissell CA. Review of ecological effects of roads on terrestrial and aquatic communities. Conserv Biol. 2000; 14(1):18-30. https://doi.org/10.1046/ j.1523-1739.2000.99084.x

- Vannote RL, Minshall GW, Cummins KW, Sedell JR, Cushing CE. The river continuum concept. Can J Fish Aquat Sci. 1980; 37(1):130-37. https://doi.org/10.1139/ f80-017

- Venables WN, Ripley BD. Modern applieds Statistics with S. Fourth Edition. New York: Springer; 2002. https://doi. org/10.1007/978-0-387-21706-2

- Violle C, Enquist BJ, McGill BJ, Jiang L, Albert CH, Hulshof C et al. The return of the variance: Intraspecific variability in community ecology. Trends Ecol Evol. 2012; 27(4):244-52. https://doi. org/10.1016/j.tree.2011.11.014

- Violle C, Navas ML, Vile D, Kazakou E, Fortunel C, Hummel I et al. Let the concept of trait be functional! Oikos. 2007; 116(5):882-92. https://doi.org/10.1111/ j.0030-1299.2007.15559.x

- Vos CC, Chardon JP. Effects of habitat fragmentation and road density on the distribution pattern of the moor frog Rana arvalis. J Appl Ecol. 1998; 35(1):44-56. https://doi.org/10.1046/j.13652664.1998.00284.x
- Ward JV, Stanford JA. The serial discontinuity concept of lotic ecosystems. In: Fontaine TD, Bartell SM, editors. The dynamics of lotic ecosystems. Michigan: Ann Arbor Science; 1983. p.29-42.

- Warren Jr. M, Pardew MG. Road crossings as barriers to small-stream fish movement. Trans Am Fish Soc. 1998; 127:637-44. https://doi.org/10.1577/15488659(1998)127\%3C0637:RCABTS\%3E2.0. $\mathrm{CO} ; 2$

- Watrin OS, Gerhard P, Maciel MNM. Dinâmica do uso da terra e configuração da paisagem em antigas áreas de colonização de base econômica familiar, no nordeste do estado do Pará. Geografia. 2009; 34(3):455-72.

- Wellman JC, Combs DL, Cook SB. Long-term impacts of bridge and culvert construction or replacement on fish communities and sediment characteristics of streams. J Freshw Ecol. 2000; 15(3):31728. https://doi.org/10.1080/02705060.2000. 9663750

- White TCR. Flooded Forests: Death by drowning, not herbivory. J Veg Sci. 2007; 18(1):147-48. https://doi. org/10.1111/j.1654-1103.2007.tb02525.x

\section{Neotropical |chthyology}

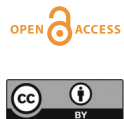

This is an open access article under the terms of the Creative Commons Attribution License, which permits use, distribution and reproduction in any medium

Distributed under

Creative Commons CC-BY 4.0

๑ 2020 The Authors.

Diversity and Distributions Published by SB

3 Official Journal of the

Sociedade Brasileira de Ictiologia

SBI

\section{AUTHOR'S CONTRIBUTION 이}

Gabriel L. Brejão: Conceptualization, Data curation, Formal analysis, Funding acquisition, Investigation, Methodology, Project administration.

Fabricio B. Teresa: Conceptualization, Data curation, Formal analysis.

Pedro Gerhard: Conceptualization, Data curation, Formal analysis, Funding acquisition, Investigation,

Methodology, Project administration.

\section{ETHICAL STATEMENT}

Fish sampling was possible due to the permit 22111-1 issued by Instituto Chico Mendes de Biodiversidade (ICMBio).

\section{COMPETING INTERESTS}

The authors declare no competing interests.

\section{HOW TO CITE THIS ARTICLE}

- Brejão GL, Teresa FB, Gerhard P. When roads cross streams: fish assemblage responses to fluvial fragmentation in lowland Amazonian streams. Neotrop Ichthyol. 2020; 18(3):e200031. https://doi.org/10.1590/1982-0224-2020-0031 